Journal of Qualitative Criminal Justice \& Criminology

\title{
An Examination of the
}

\section{Researcher Guard Role:}

Bringing Prison Fieldwork

into the 21st Century

Scott Chenault ${ }^{1}$

${ }^{1}$ University of Central Missouri

Published on: Oct 01, 2014

DOI: $10.21428 / 88 d e 04 a 1.9915 a 876$

License: Creative Commons Attribution 4.0 International License (CC-BY 4.0). 


\begin{abstract}
In 1986, James Marquart published a seminal article on qualitative methodology in Justice Quarterly. In that piece he presented the strengths and weaknesses associated with the researcher guard role he used while conducting a prison ethnography in Texas. His method led to data that is still central to our understanding of prison culture. However, in the past 30 years, correctional philosophy and practice have undergone significant shifts in the United States. Despite these shifts, there has been a dramatic decrease in prison ethnography during the same time period. This article presents a modern adaptation of Marquart's method, based on a recently completed ethnography of officer culture in a Midwestern state.
\end{abstract}

\title{
Introduction
}

There is a rich and varied tradition of ethnographic research in American prisons; virtually all of the seminal works in prison sociology are based on participant observation (Clemmer, 1940; Irwin, 1970; Jacobs, 1977; Sykes, 1958). Despite this rich tradition, field work in corrections went bust at approximately the same time the American prison population was booming. Loic Wacquant characterized the state of American correctional research as an "eclipse of prison ethnography" (2002, p. 371). Other nations, most notably Great Britain, have not suffered the same fate, instead maintaining the art of prison ethnography (see Bennet, Crewe, \& Azrini, 2008; Crawley, 2006; Crewe, 2005; Liebling, 1999).

In 1986, just as the eclipse was coming into focus, James Marquart (1986a) published an article in Justice Quarterly that remains a seminal critique of prison research methodology. Marquart lamented the prominence of survey methodology in exploring the prison, especially prison culture. He then outlined an argument for performing prison research through full participation as a guard. For a variety of reasons (see Patenaude, 2002; Simon, 2000; or Wacquant, 2002) his methodology has rarely been replicated over the past 25 years. I recently completed an ethnographic study of correctional officer culture using similar, but distinct, methods. The methodology advocated by Marquart is an invaluable approach to fully understanding the cultural complexities of modern prison life. However, Marquart's writing is now over 25 years old (his research is over 30 years old) and should be revisited.

In the remainder of this article, I will lay out the shifts in correctional practice that necessitate a different methodological approach. Then I will examine the similarities and differences between Marquart's researcher guard method and my own modified participant observation method of conducting field work in prison. The differences between the two methods should demonstrate the way the modified participant observer role accentuates the strengths of Marquart's method while minimizing the weaknesses. 


\section{Field work context: Shifts in correctional practice}

In 1974, Robert Martinson published his infamous "What Works" article which was widely interpreted as concluding that rehabilitation had been a failure (Martinson, 1974). Then, in 1975, the Federal Bureau of Prisons - which had championed rehabilitation-abandoned the medical model (Earley, 1993). As a result by the early 1980's rehabilitation had virtually vanished as a goal of corrections (Zimring \& Hawkins, 1995).

Punishment, specifically incapacitation, replaced rehabilitation as the goal of corrections (Roberts, 1996). A number of policies were enacted to uphold the goal of incapacitation. The shift in philosophy led to changes in sentencing structures. Indeterminate sentencing was replaced by determinate. In 1987, the United States Sentencing Commission created a set of sentencing guidelines (Jacobsen, 2005; Ruddell, 2004; Walker, 2001) which were designed to reduce discretion and resulted in longer sentences for most crimes (Jacobsen, 2005).

The shift to determinate sentencing and implementation of sentencing guidelines reduced discretion in sentence length. However, inmates were still eligible for early release from prison based on good behavior, and in 1984 the state of Washington first implemented a "truth in sentencing" law (Ruddell, 2004). The law required inmates to serve a pre-determined portion of their sentence (typically 85\%) before being eligible for release. Just over half of all states have adopted "truth in sentencing policies" (Miller, 2004). Requiring inmates to serve $85 \%$ of their sentence before the possibility of release eliminates an incentive for good behavior, and these changes in sentencing structure reduced inmates' incentive to cooperate with prison staff or seek treatment (Ruddell, 2004).

Along with changes in sentencing structure, the war on drugs was a centerpiece in the new incapacitation philosophy. Drug prohibition policies greatly increased the number of people sent to prison for non-violent drug-related crimes (Drucker, 2011; Jacobsen, 2005). According to Jacobsen (2005), the estimated 25\% increase in prison population between 1980 and 2001 was due to non-violent drug convictions.

The combination of punitive drug policies and revised sentencing structures significantly changed prisons during the 1970s and 1980s. From the 1920s until the 1970s, rates of imprisonment remained stable at around 100-150/100,000 (Drucker, 2011; Gottschalk, 2006). In the 1970s, the prison population began to grow; the growth accelerated in the 1980s, and the incarceration rate is now over $500 / 100,000$ (West \& Sabol, 2008). The United States prison population is now the largest in US history (Austin \& Irwin, 2012). Overcrowding was a problem at various times throughout correctional history (Gottschalk, 2006; Jacobs, 1977) but it was never as prevalent as now. Overcrowding results in officers being outnumbered and makes it difficult for officers to have personal relationships with inmates. 
The changes in sentencing policy in the early 1980s also changed inmate demographics. The prison population became proportionately less violent and older over the last 30 years (Ruddell, 2004). The long sentences associated with incapacitation meant inmates were likely to grow old in prison, and the focus on drug crimes meant a higher proportion of non-violent offenders. In addition, from 1980-1996, imprisonment rates of Latinos increased by $235 \%$, Blacks by $184 \%$, and Whites by $164 \%$ (Blumstein \& Beck, 1999). This meant there were more minorities in prison than ever before. At the same time, an us vs. them attitude toward criminal justice officials developed among minorities in urban areas (Clear, 2002). The combination of a higher proportion of minorities and a shift in minority attitudes led to a more confrontational interaction style between officers and inmates.

In addition to the substantive changes to the prison environment over the last 30 years, there have also been significant changes in prison accessibility. Over the last three decades, prison administrators have become increasingly fearful of inmate lawsuits. Inmates began to sue prisons and their administrators in earnest in the 1960s, and the number of suits per year increased dramatically until 1996 (Palmer \& Palmer, 2010). These lawsuits resulted in apprehension by administrators about letting outsiders view the inner workings of prisons. This apprehension was still developing during Marquart's research. One of the most impactful rulings in prison administrators (Ruiz v. Estelle, 1980) happened in Texas after Marquart began his work. This decision mandated judicial oversight of the Texas Department of Corrections for nearly 25 years and affected how most prison administrators operated their systems.

The shift to a punitive focus has also led to correctional administrations who are more opposed to allowing researchers into prisons (Wacquant, 2002). Others point to causes such as the relative comfort of modern prison settings compared to their predecessors (Simon, 2000) or rising IRB standards (Patenaude, 2004) that block either desire or access to conducting prison fieldwork. The end result of all these factors is a hardening of prisons as research targets.

Compared to Marquart's time, today's prisons are much larger and are typically less violent. The prison homicide rate has dropped by over $90 \%$ since Marquart's research (Mumola, 2005). Further, the rate of assaults on officers has also dropped significantly in the last 30 years (Byrne \& Hummer, 2008). The result of all of these changes is a drastically different world than the one Marquart studied. The remainder of this article examines Marquart's method and suggests an updated approach to prison fieldwork that is more appropriate for the current correctional context.

\section{Methodological similarity}

Marquart worked as a researcher guard for 19 months at a single prison within the Texas prison system. In contrast, I worked as an officer for two years at four different prisons within the Prairie

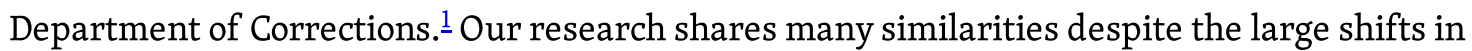


correctional population and practice that have occurred over the past three decades. I was upfront with all members of the correctional staff regarding my purpose and the focus of my research. Like Marquart, I encouraged staff to ask me questions about my research and answered all questions as honestly as possible. One critical difference in our work involved interactions with inmates. Whereas Marquart interacted openly and honestly with inmates as well as officers, I did not. I did not inform any inmates of the reason for my presence in the institution. I interacted with inmates as if I were a new officer and allowed them to draw their own conclusions. In practice, this meant virtually all inmates believed I was a new officer who was just starting at that particular institution.

\section{Proving grounds}

One of the themes of Marquart's work is the constant need to prove himself to his co-workers. The need to develop rapport with subjects is critical in qualitative fieldwork (Berg, 2007). However, this need is much more pronounced when conducting prison fieldwork (Carroll, 1974; Giallombardo, 1966). Correctional staff are formally trained and informally conditioned to be suspicious of outsiders (Kauffman, 1980; Lombardo, 1989; Rhodes, 2004). All new correctional officers go through an unspoken proving period before being accepted into the officer culture (Conover, 2001). In addition, a prison participant researcher has to constantly prove he/she is not a "spy or government agent" (Marquart, 1986a, p. 18). Participant observers who openly admit to conducting research must not only prove capable of doing the job but must also prove they are not a threat to the officers. The need to prove oneself twice is critical because as Marquart says, "I had to earn their favor before being accepted, respected, and able to collect data" (Marquart, 1986a, p.15).

Those hoping to conduct participant observation in a prison setting must prove they can adequately perform the occupational tasks, and that they are not spies While the burden is shared by all prison participant observers, the methods for proving oneself vary depending on the context. Prison fieldworkers suggest a variety of methods for gaining acceptance and respect including accepting difficult assignments, demonstrating a willingness to stand up to inmates, and engaging in social activities with other officers (Marquart, 1986a; Conover, 2001; Crouch, 1980). However, Marquart argues that the most efficient way to gain acceptance and respect is to fight an inmate (1986b).

Marquart lays out in great detail his "fortunate" encounter with a violent inmate (1986b, p.20). Marquart's willingness to physically engage an inmate granted him access to a wealth of data on officer culture. Officers (and most academics who examine prisons) present the world of prison work as extremely dangerous (Crawley \& Crawley, 2007; Liebling, 2008). While the actual danger inherent in prison work is debatable, the perception of danger means courage is a valuable trait among officers (Conover, 2001; Crawley, 2006; Kauffman, 1988). 
The perceived dangerousness of the job and the value placed on courage in officer culture remain constant in modern corrections. The reality of modern corrections is that the rate of violence is much lower than it was 30 years ago (Byrne \& Hummer, 2008; Eichenthal \& Blatchford, 1997; Mumola, 2005). A new officer who is forced to physically engage with an inmate will earn immediate respect and acceptance today just as they would in Marquart's time. However, in most prison systems the need to engage in a spontaneous ${ }^{2}$ physical altercation with an inmate is rare. What Marquart viewed as the most efficient way for a participant observer to gain acceptance, and therefore access, is now a very rare occurrence. Instead, modern prison participant observers must gain access through more nuanced channels.

In modern correctional settings, there are various methods for gaining the respect and acceptance of correctional officers. The underlying theme of all of these methods is for the new officer (or participant observer) to know his place and adhere to dominant cultural norms which are often in direct contradiction to formal training. New officers and observers alike must show appropriate deference to veteran officers and quickly adapt to culturally accepted methods of job performance regardless of the formal rules.

The notion of discarding formal rules and adhering to culturally accepted norms is potentially problematic. However, there are limits to the acceptance of cultural norms and rejection of formal rules in the area of physical violence by officers. During his research, Marquart found a complex informal system of physical coercion by correctional officers (Marquart, 1986b). In the early 1980s, Texas prison cultural norms encouraged officers to physically assault inmates in spite of the formal rules prohibiting the behavior. In contrast, during two years of field work, I never saw an officer assault an inmate. Although violation of most formal rules was tolerated by fellow officers and to some degree by the administration, physical violence toward inmates was viewed as universally taboo. $\underline{3}$

An example from an overnight shift at a maximum security prison may clarify the need to disregard formal rules in favor of adopting cultural norms.

I worked the overnight shift with two veteran officers (Murphy and Bumble) and a new officer (Oldje) who was working his first shift. We were assigned to a housing unit that use open bays with several sets of bunkbeds instead of individual cells. This unit has a control center, or bubble, located in the middle with large windows that allow the officers to watch the inmates in the bays. Due to the design of the housing unit, there is much more inmate interaction on the overnight shift than in other parts of the prison. After about an hour, the following exchange took place:

Oldje: Hey he's passing and receiving. (Odlje then pointed out the window at one of the inmates.)

Murphy: Did you see him take something? 
Oldje: Yeah he came over and handed a book to that other guy, then a few minutes later he took it back.

Murphy: Okay that's his brother but you're right that's passing and receiving.

Oldje: We can confiscate that right? Murphy: Yeah you can go get it if you want to.

Oldje then backed off his bravado a little bit and said, "Okay I might here in a few minutes." Murphy pursued the issue and said, "No, really man you can go get it, if you want to confiscate it just walk out there and take it from him."

Oldje: Yeah maybe I will in a little bit.

Murphy: If you want me to, I'll go out there with you and we can get it.

Oldje: No maybe in a few minutes.

A minute or two after this the inmate returned to his bunk, and sat looking toward the dayroom.

Oldje was still watching him and said "Now he's staring at us he knows we're coming; see, now he knows that we're watching him, so him and his homies are watching us."

After a few more minutes the issue was dropped, and Oldje never entered the bay to confiscate the item, nor did he write an infraction for the inmate. This exchange illustrates two key components of gaining acceptance as a newcomer to modern correctional work.

First, newcomers must adhere to cultural norms. During academy training, new officers are told to write a misconduct report for every inmate infraction they encounter no matter how trivial. The idea that small things lead to big things is repeatedly stressed, so new officers believe that even seemingly minor infractions may lead to a riot if not corrected. In contrast, the informal officer culture stresses keeping the peace within the institution. This often means ignoring or informally handling anything seen as a minor transgression. Passing and receiving is an offense which is nearly always seen as a minor offense by experienced officers. In this case the item being passed was a book, and it was passed between two brothers making it the most minor of offenses.

Despite the triviality of the offense, Oldje was determined to not only write a report but also confiscate the item, although the report was likely to be discarded with the inmate receiving little more than a verbal warning. However, confiscating the item involves a confrontation with the inmate, in an open bay with approximately 90 other inmates. Confiscating the item threatens the institutional peace veteran officers strive to maintain. In spite of this, the veteran officer encouraged Oldje to confiscate the item. 
This encouragement stems from the second component of gaining acceptance. Unlike in Marquart's time, modern correctional officers are rarely required to engage in spontaneous violence within the prison. Consequently, modern officers have fewer opportunities to demonstrate the courage necessary to physically engage an inmate. Oldje's interaction demonstrates one way officers address the lack of physicality in modern prisons. Modern officers' courage may be gauged based on their willingness to confront inmates, especially inmates who seem to be disrespecting the officer.

In this case, Oldje believed he had been disrespected by the inmate. His comment about how the inmate and "his homies" were "looking at us" demonstrates the perceived disrespect. Oldje believed the inmate knew he violated the rules and was flaunting his violation. Despite the informal norm of ignoring this type of violation, Oldje created a rare opportunity to demonstrate courage. The combination of disrespect and perceived danger created a chance for Oldje to prove himself and to be accepted on his first night. Instead, he shied away from the confrontation and was neither accepted nor extended respect.

Oldje's refusal to confront the inmate was seen as a lack of courage and an inability to internalize cultural norms. This meant that Oldje was not accepted and instead was ostracized by the veteran officers. Officer Oldje was never accepted by his peers and quit the job after only three weeks.

While this example involved a new officer, the same principles apply to a participant observer in the prison setting. Participant observers in a prison setting must quickly adapt to the cultural norms of the setting in order to be accepted and gain access to data. Just as Marquart noted, fighting an inmate brought immediate acceptance and respect; modern officers must demonstrate courage when given the opportunity. Modern officers are not likely to be asked to fight an inmate, but a participant observer must be willing to confront an inmate forcefully if the need arises. The more common form of acceptance depends on deference to more experienced officers and adoption of cultural norms.

A humorous example of deference shown to a veteran officer may illustrate this point. During an evening shift, I was treated as a new officer and subjected to a creative form of hazing. Although this example is unique to the particular institution, similar rituals exist across the Department of Corrections (DOC).

Shortly after dinner, I was in the dining hall with several other officers. Corporal Julius was running the yard-in charge of assigning tasks to each officer over the course of the night. The responsibility of assigning specific tasks allows the corporal who is running the yard to haze new officers. Julius asked me, "Have you ever done dining before?" "No," was my reply.

Julius said, “Well then, I guess you're going to have to do it. Here's the deal, when the inmates come into dining they have to have their shirts tucked into their pants; if they are wearing a white shirt or a 
khaki button down, their sweatshirts can hang out. They also are not allowed to wear anything on their head other than religious headgear, and they can't wear shower shoes to dining. Also they can't have their headphones on and they can't be flashing any gang shit, nothing hanging down out of their pockets, you got it?" "Yeah."

After that Julius added, "Alright, here's the deal' we are going to play Big Daddy Yum Yum. You're going to stand at the front of the serving line and make sure all the inmates are following the dress code. I'm going to stand at the end of the line with Kodos and make sure you don't miss any. If you miss one, then for the rest of the night any time I ask you what my name is you're going to say, Big Daddy. Then I am going to ask you and how does Big Daddy taste? And you are going to say, Yum Yum."

Julius then laughed while walking away, as Kodos said, "I'm going to help him make sure that when you screw up we catch it." Officer Jones then told me, "I'm going to stand over here with you and distract you to make sure you screw this up."

After a few minutes, inmates began to enter the dining hall, and I quickly realized it was impossible to enforce the dress code. The temperature was in the 20s outside, and all the inmates were wearing coats when they entered the dining hall. The coats hung lower than their shirts, and I could not see if the inmates' shirts were tucked in or not. It was only clear if inmates' shirts were tucked in after the inmates sat at a table and removed their coats. When dining was complete, I was told I had missed three shirts. Despite my failure, Julius did not follow through with the Big Daddy Yum Yum routine. Officer Jones approached me shortly after dining and said, "You missed three, but don't worry about it, man, I still miss them; it's not that big of a deal."

The Big Daddy Yum Yum Game is played with new officers to gauge their willingness to accept hazing. The three veteran officers in the dining hall worked together to embarrass me and make me feel uncomfortable. The point of the game is to place the new officer in a no win situation. The veteran officers then watch to see if the newcomer complains about the inherent unfairness of the game. I laughed at the game, did not complain, and was willing to participate in the ritual. The veteran officers granted me acceptance based on my response. Jones told me not to worry about it because I handled the hazing appropriately.

My role in this hazing ritual established me as an officer. Although the other officers were well aware of my status as a researcher, they treated me like one of their own. From then on they spoke freely in front me, acted naturally regardless of my presence, and felt comfortable enough to share insights about their job and culture during interviews. In short, my willingness to embarrass myself allowed me access to the richest data. 
The differences in context between Marquart's work and my own mean that even in areas of similarity (the need to gain acceptance and respect) there are differences in technique. The greater difference between our research lies in the role adopted by the researcher. This article now turns to a brief comparison of Marquart's researcher guard role and my own modified participant observer role.

\section{Methodological difference}

The researcher guard role Marquart used is one possible approach to the ethnographic research method. Ethnography allows the researcher to get close to the people being studied and "to discover the details of their behavior and the innards of their experience" (Atkinson \& Hammersly, 1998, p.119; also see Finch, 1986; Stacey, 1988). Ethnography creates access to a variety of backstage behaviors that other methods cannot access. In addition, the combination of participant observation and supplemental interviewing allow for a triangulation of data to more accurately depict the prison world (Berg, 2007; Denzin, 1978; Rock, 2001). This process also produces an in-depth picture of the intangible elements of culture that are difficult for other methods to analyze (Neyland, 2008).

While ethnography is easily the best method for examining culture, including prison culture, it is a difficult method to use. Ethnographic fieldwork requires access to a field site, (for a discussion of the difficulty of gaining access for prison ethnography see Patenaude, 2002 or Chenault, 2012), extensive emotional labor, and extended time (sometimes years) for data collection (Berg, 2007). In addition, there are different methods available for conducting ethnography. Marquart employed a more traditional participant observer role which he titled the researcher guard role. In contrast, I adopted a modified participant observer role which accentuates the strengths and minimizes the weaknesses of the full participant role.

\section{Researcher guard role}

The primary strength of the researcher guard role is the insider status it affords the researcher. The role allows the researcher to look the part by wearing the officer uniform and being regularly present within the institution. Further, the shared experiences of training and day to day interaction within the correctional officer role create a common ground for the researcher and subjects. As a researcher guard, I experienced conducting strip searches, working the yard in extreme elements, unpleasant training scenarios, and all the other negative aspects of the job that help bond officers together. These shared experiences and a researcher's regular presence help grant access to the richest data within the prison culture.

However, taking on a role as a full participant also carries some inherent weaknesses. Marquart identified three major weaknesses with the researcher guard role. First, due to his employment as a full-time officer, Marquart faced restricted movement and contact with other officers during the first several months of data collection (Marquart, 1986a, p. 22). New officers are typically assigned posts 
which minimize officer movement. Officers in these posts have little interaction with other officers. This can be a major weakness depending on the subject of the research.

If the researcher is examining inmate culture, a housing unit post could be beneficial, because the entire working day will be spent in a position to observe inmate behavior within the unit. However, even in this situation the researcher will not have access to inmate behavior on the yard, at work details, in the dining hall, etc. Also, the researcher will only have access to one housing unit which could be an outlier in terms of inmate culture.

If, as I experienced, the researcher is examining officer culture, a housing unit severely limits the available data. Housing units are typically staffed by only three to five officers, meaning that a six month housing unit assignment would only grant access to between five and eight other officers who all work in the same place. Marquart lamented the first few months of his research due to the lack of "needed mobility to traverse the prison compound" (Marquart, 1986a, p. 22). Freedom of movement and exposure to various subjects is critical for the effective examination of culture.

The second major weakness of the researcher guard method is the demands of the correctional officer role. The role of researcher guard allows access to constant informal interviewing of subjects. However, the research agenda must always be superseded by the duties of the officer role. This is most problematic in terms of security issues, as Marquart said, "as a guard it was necessary to be security conscious first and a researcher second" (Marquart, 1986a, p. 23). In practice this again limits the researcher's ability to collect full data. There are times when the researcher-guard must ignore pressing research questions in order to fulfill the occupational duties of the guard role. For example, if an inmate suddenly assaults another inmate on the yard, there are a variety of questions related to prison culture the researcher will want to ask. If the researcher is in a researcher guard role, he/ she will instead have to respond to the incident, secure both subjects, and complete paperwork regarding the incident. Only after several hours of completing occupational duties will the researcher be able to refocus on data collection. By that time, some of the initial questions may be forgotten and the immediate perceptions of the people around the event will have been colored by retelling the story and by others' perceptions.

The final major weakness of the researcher guard method relates to reactivity. Marquart used the term reactivity to refer to the potential of the researcher's presence to influence the behavior of research subjects. Typically, the term reactivity is used to describe biasing effects during qualitative interviewing (Babbie, 2010; Chadwick, Bahr, \& Albrecht, 1984). The common term for bias caused by participant observation is the Hawthorne effect, wherein subjects change their behavior due to the presence of the researcher (Roethlisberger \& Dickenson, 1939). 
The Hawthorne effect is typically short-lived and can be overcome by a skillful ethnographer who is able to make himself invisible in the social setting (Berg, 2007). Invisibility can be achieved by participating in the normal routine of subjects, by being routinely present, and by forming personal relationships with subjects (Stoddart, 1986). Marquart provided examples of each of these behaviors in his method. He worked a full time position as an officer making him routinely present in the setting. He engaged in the normal routine of a correctional officer both on the job and off, including engaging in after-hours recreational activity with other officers (Marquart, 1986a, p. 23). Finally, and perhaps most importantly, he formed personal relationships with many of the officers. This fact is supported by his later return to the setting, and the continued support the officers gave him.

Overall, Marquart's researcher guard role was able to minimize reactivity on the part of other officers. However, because he was open with inmates about his position as a researcher, the possibility of reactivity extends to inmates as well. Marquart discussed the personal relationships he formed with not only officers but also with a few inmates. These relationships minimized reactivity in his research, but would be very difficult to form in a modern correctional setting without alienating correctional officers.

The inmates Marquart (1986a) befriended (he discussed lifting weights and drinking coffee with inmates) were building tenders-inmates who served as de facto officers helping to oversee and manage their fellow inmates. This specialized role made it acceptable to associate with the building tenders without violating officer cultural norms. The practice of using building tenders was banned by Ruiz v. Estelle, which effectively ended the ability to socialize so freely with inmates. Therefore, although reactivity was actually a strength of the researcher guard role for Marquart it would be a weakness in a modern setting.

\section{Modified participant observer}

The modified participant observer role that I employed addresses each of the weaknesses while maintaining the primary strength of Marquart's approach. Like Marquart, I was in uniform throughout my ethnographic observations and worked as an officer. However unlike Marquart, I was not technically employed by the DOC. This technicality provided a great deal of flexibility in institutional assignments and work assignments within institutions. In practice, I conducted my research very much in line with typical participant observation techniques. However, the added autonomy of being able to choose my own work assignments modified the traditional participant observer role enough to overcome the weaknesses in Marquart's role.

I began the research by completing the five week correctional officer training academy in its entirety. This was required by the DOC to gain access to their facilities, but it also served as a rich data source. Completion of the academy was critical to my modified participant observer role. Academy training 
taught me how to act like an officer. The language and mannerisms I learned in the academy coupled with my uniform meant I was indistinguishable from any other new officer. Despite my appearance, I disclosed my role as a researcher to all the officers I worked with throughout the project. The combination of looking the part and having shared training experiences helped me earn insider status. The modified participant observer role maintained the strengths of the research guard role and addressed the three weaknesses of the researcher guard role.

\section{Movement restrictions}

The researcher guard role greatly restricts the range of data, interactions, and events available to the researcher. In contrast, due to my modified role, I was able to work in a variety of locations. I was not paid for the hours I worked and was not assigned to specific institutions or shifts. Instead, the department treated me as an unpaid super-intern allowing me unfiltered access but without any financial commitment to me. This meant I was able to choose when and where I worked during my research. ${ }^{4}$ Yard officers have the most freedom of movement within the institution and as a result interact with the highest number of fellow officers, by far. Due to this, I spent a considerable amount of my time working with yard officers. In general, new officers are nearly never assigned to the yard, so my modified role immediately provided me access to otherwise inaccessible data.

In addition, although yard officers have a great deal of autonomy, their duties and cultural implications are significantly different from housing unit officers. Officer post assignments in Prairie are in six month increments. If I somehow was assigned to the yard as a researcher guard, I would have restricted access to housing units for at least six months. The modified participant observer role allowed me to gain insight into the entire culture in a timelier manner.

My ability to choose when, where, and with whom I worked allowed me to collect data in a purposive and theoretically based manner. I spent my first day on a new shift or at a new institution working with an officer I knew from the academy. During this first shift, I employed purposive sampling to identify potential subjects to work with and interview. Subject identification was based on two criteria: their post and their openness. First, I sought to experience all officer tasks; therefore I tried to identify officers with diverse post assignments (see Lofland, Snow, Anderson, \& Lofland, 2006). Second, officers were chosen based on their perceived willingness to reveal information regarding their culture (Hammersly \& Atkinson, 2007).

As the research developed, I began to employ theoretical sampling to accrue subjects for observation and interviews. Theoretical sampling involves returning to the field after initial analysis and purposely seeking subjects that can add detail to emerging themes in the research (Charmaz, 1994; Charmaz \& Mitchell, 2001). For example, in my research an early theme emerged regarding the issue of female officers being compromised by male inmates. There was concern among male officers and command 
staff that female officers were likely to become romantically involved with male inmates. This concern led to differential treatment of female officers by male officers and command staff. After this theme emerged, I sought to observe and work with more females in the male facilities.

The sampling I employed greatly improved the richness and quality of the data. In a true researcher guard role, I would have interacted with few officers during the first six months of my research (similar to Marquart's assignments). In addition, there are a number of experienced officers who refuse to interact with new officers until they have been with the department for at least one year. I was able to work with and informally interview several of these experienced officers because I was not a new officer.

\section{Job-related restrictions}

The second major weakness of the researcher guard role is the requirement to perform job-related duties. Due to my modified status, while I was given institutional tasks at various times the majority of my time was spent with other officers. The topic of my research was officer culture, so it made sense to be around officers the majority of my time in the field. This meant I could focus on the research while other officers focused on security. Even when security needs arose, I was generally able to focus on observing how the officers handled the situation instead of handling the situation personally.

For example, on an evening shift in the supermaximum security unit, inmate Snaken took the 13-inch television in his cell, placed it inside a pillow case, and swung it into his cell wall. He then found two 6inch pieces of glass in the debris and wired them to each of his hands. This gave him two large homemade knives to use as weapons. He then covered the window to his cell and began screaming, "Come in and get me I'm going to kill you motherfuckers!" (Owmel, CSCI 4-06-09)

During the next four hours, the Lieutenant on duty tried to talk Snaken into giving up. Finally, the Lieutenant selected two teams of five officers dressed in riot gear to enter the cell and subdue Snaken. All ten officers selected were male, and all three new officers on the shift were selected. Due to my role as researcher, the Lieutenant refused to allow me to enter the cell. Instead I stood in the briefing room as the officers prepared and was able to focus on observing the officers' behavior. Due to my standing as a pseudo officer, I was allowed to follow one of the five man teams into the cell and observed the incident without any job-related responsibilities. This observation would not have been available for either the researcher guard or the standard researcher. The researcher guard would have been required to be a member of the extraction team. In contrast, the standard researcher would not have been allowed near the incident.

Finally, after the incident, I conducted informal interviews with the officers involved while they were taking off their equipment and beginning to write their reports. This allowed me to get immediate perceptions of what had occurred from the officers. 


\section{Reactivity}

The final weakness, reactivity, remained a potential issue for me. The challenge was to make myself invisible to minimize the impact I had on the setting. In terms of other officers, I achieved invisibility, as did Marquart, by wearing a uniform and by using the language of officers which I learned during formal training. I also engaged in minor deviance, such as eating food from the segregation food cart. While not as dramatic as engaging in physical violence toward inmates, acts of minor deviance assured the officers I was not going to inform on them to the administration. While I cannot be completely sure I did not influence any of the research subjects, an incident from my academy training illustrates the degree of invisibility I was able to achieve with officers.

There were two psychology doctoral students from a different university who were planning to conduct Prison Rape Elimination Act research for the department. Both were white females in their mid-20s who were working as interns for the department and were required to complete portions of the training. At the end of our initial week of training, it was time for the first of many exams. Once cadets completed the exam, we walked to the break room and waited for the results. After the interns took the exam, they were excused for the rest of the day. All of the cadets sat around a table in the break room chatting.

Jackie, a new officer, said, "They must be smart if they can just come when they want to," referring to the interns. Jackie's resentful tone was clear and was quickly followed by Marge, a female caseworker, discussing the inappropriate appearance of the interns. Marge said, "They both look like they are 12, and the one is dressed like a prostitute, I mean who wears that to a prison."

The implication was that the interns were outsiders; however, I was sitting with the officers and my group membership was never questioned. In fact, no one even acknowledged that my official role was quite similar to both of the young interns. There was no apology or comment of how I was different than them. Instead, I was just one of the new officers who had to return to training while the outsider interns got to leave early. This exchange shows clearly that by wearing the uniform, my use of appropriate jargon, my shared training experiences, and participation in various after-hours activities, I gained a level of invisibility. The officers accepted me and acted naturally in front of me.

As opposed to the researcher guard role, I addressed the potential for influencing inmate behavior through minor deception. I did not disclose to inmates who I was or why I was in the institution, but let them reach their own conclusions. I was prepared (including informed consent forms) to explain my research to inmates if asked, but at no time did any inmate ask who I was or what I was doing in the prison. The inmates all assumed, based on my appearance and behavior, that I was yet another new officer. Due to this assumption, I have no reason to believe the offenders acted any differently during my observations than at any other time during their sentence. 


\section{Conclusion}

The preceding discussion points toward a new approach to qualitative prison research. Several of the techniques discussed for gaining access as a researcher are also critical for new officers since the socialization process for new officers has shifted substantially in the last 30 years. New officers, much like researchers, are now left to gain acceptance through nuanced channels of norm acceptance and deference to senior officers. The full socialization process for new officers is beyond the scope of this article, but the many of the insights applied to researchers here can also be applied to new officer socialization.

Marquart's ethnographic prison research increased understanding of both officer and inmate culture. While his work was another in a long line of qualitative prison research efforts (Clemmer, 1940; Sykes, 1958), his method was unique. The idea of conducting research from the researcher guard perspective carried a variety of strengths and weaknesses but was an effective method. However, given the shifts in correctional philosophy and practice over the past 30 years, a new approach is needed to successfully conduct prison fieldwork.

The modified participant observer role I advocate minimizes the weaknesses of Marquart's approach while retaining its strengths. Regrettably, the tradition of prison ethnography which much of our understanding of corrections was built on has nearly vanished in the last 30 years. If we are to regain an understanding of current prison culture, the modified participant observer role will be a valuable tool.

\section{References}

Atkinson, P. \& Hammersly, M. (1998). Ethnography and Participant Observation. In Strategies of qualitative inquiry. N. Denzin. \& Y. Lincoln (Eds.) Thousand Oaks, CA: Sage.

Austin, J. \& Irwin, J. (2012). It's about time: America's imprisonment binge (4th ed.). Belmont, CA: Wadsworth-Cengage Learning.

Babbie, E. (2010). The practice of social research. (12th ed.). Belmont, CA: Wadsworth-Cengage Learning. Bennet, J., Crewe, B. \& Wahidin, A. (2007). Understanding prison staff. Portland, OR: Willan Publishing. Berg, B. (2007). Qualitative research methods for the social science (6th ed.). Boston, MA: Allyn \& Bacon. Blumstein, A. \& Beck, A. (1999). Population growth in U.S. prisons 19801996. Crime and Justice: A Review of the Research, 26, 17-61.

Byrne, J. \& Hummer, D. (2008). The nature and extent of prison violence. In The Culture of Prison Violence. J.Byrne, D. Hummer, \& F. Taxman, (Eds.). Boston, MA: Pearson. 
Carroll, L. (1980). The frustrated hack. In The Keepers: Prison Guards and Contemporary Corrections. B. Crouch,(Ed.) Springfield, IL: Charles C. Thomas.

Chadwick, B., Bahr, H., \& Albrecht, S. (1984). Social science research methods. Englewood Cliffs, NJ: Prentice Hall.

Charmaz, K. (1994). The grounded theory method: An explication and interpretation. In More Grounded Theory Methodology: A Reader. B. Glaser (Ed.). Mill Valley, CA: Sociology Press.

Charmaz, K. \& Mitchell, R. (2001). Grounded theory in ethnography. In Handbook of Ethnography. P.Atkinson, A. Coffey, S. Delamont, J. Lofland, \& L. Lofland (Eds.). Thousand Oaks, CA: Sage.

Chenault, S. (2012). Getting into the "belly of the beast:" A guide to gaining access for prison ethnography. ACJS Today, 37 (3), 1-12.

Clear, T. (2002). The problem with "addition by subtraction": The prison crime relationship in low income communities. In Invisible Punishment: The Collateral Consequences of Mass Imprisonment. M. Mauer \& M. Chesney-Linds (Eds.). New York, NY: The New Press.

Clemmer, D. (1940). The prison community. New York, NY: Christopher Publishing.

Conover, T. (2001). NewJack: Guarding Sing Sing. New York, NY: Random House.

Crawley, E. (2006). Doing prison work: The public and private lives of prison officers. Portland OR: Willan Publishing.

Crawley, E. \& Crawley, P. (2007). Understanding prison officers: Culture, cohesion and conflict. In Understanding Prison Staff. J. Bennet, B. Crewe, \& A. Wahidin (Eds.). Portland, OR: Willan Publishing.

Crewe, B. (2005). Prisoner society in the era of hard drugs. Punishment and Society, 7, 457-481.

Crouch, B. (1980). The book vs. the boot: Two styles of guarding in a southern prison. In The Keepers: Prison Guards and Contemporary Corrections. B. Crouch (Ed.). Springfield, IL: Charles C. Thomas.

Drucker, E. (2011). A plague of prisons: The epidemiology of mass incarceration in America. New York, NY: The New Press.

Earley, P. (1993). The hot house: Life inside Leavenworth prison. New York, NY: Bantam Books.

Eichenthal, D. \& Blatchford, L. (1997). Prison crime in New York state. The Prison Journal, 77, 456-466.

Finch, J. (1986). Research and policy: The uses of qualitative research in social and educational research. London, England: Falmer. 
Giallombardo, R. (1966). Society of women: A study of a women's prison. New York, NY: John Wiley \& Sons. Gottschalk, M. (2006). The prison and the gallows: The politics of mass incarceration in America. New York, NY: Cambridge University Press. Irwin, J. (1970). The felon. Newark, NJ: Prentice-Hall.

Jacobs, J. (1977). Stateville: The Penitentiary in mass society. Chicago, IL: The University of Chicago Press. Jacobsen, M. (2005). Downsizing prisons: How to reduce crime and end mass incarceration. New York, NY: New York University Press.

Kauffman, K. (1988). Prison officers and their world. Cambridge, MA: Harvard University Press.

Liebling, A. (1999). Doing research in prison: Breaking the silence? Theoretical Criminology, 3, 147-173.

Liebling, A. (2008). Why prison staff culture matters. In The Culture of Prison Violence. J. Byrne, D. Hummer, \& F. Taxman (Eds.). Boston, MA: Pearson.

Lofland, J., Snow, D., Anderson, L., \& Lofland, L. (2006). Analyzing social settings: A guide to qualitative observation and analysis (4th ed.). Belmont, CA: Wadsworth.

Lombardo, L. (1989). Guards imprisoned: Corrections officers at work. Cincinnati, OH: Anderson Publishing.

Marquart, J. (1986). Doing research in prison: The strengths and weaknesses of full participation as a guard. Justice Quarterly, 3, 1532.

Marquart, J. (1986). Prison guards and the use of physical coercion as a mechanism of prisoner control. Criminology, 24, 347-366.

Martinson, R. (1974). What works? Questions and answers about prison reform. Public Interest, 35, 2254.

Miller, M. (2004). Sentencing reform "reform" through sentencing information systems. In The Future of Imprisonment, M. Tonry, (Ed.). New York, NY: Oxford University Press.

Mumola, C. (2005). Suicide and homicide in state prisons and local jails. Bureau of Justice Statistics Special Report. Washington DC US Government Printing Office.

Neyland, D. (2008). Organizational ethnography. Thousand Oaks, CA: Sage. Palmer, J. \& Palmer, S. (2010) Constitutional rights of prisoners (7th ed.) Cincinnati, OH: Anderson Publishing.

Patenaude, A. (2004). No promises, but I'm willing to listen and tell what I hear: Conducting qualitative research among prison inmates and staff. The Prison Journal, 84, 69S-91S. 
Rhodes, L. (2004). Total confinement: Madness and reason in the maximum security prison. Berkeley, CA: University of California Press.

Roberts, J. (1996). Reform \& Retribution: An illustrated history of American prisons. Lanham, MD: American Correctional Association.

Rock, P. (2001). Symbolic interactionism and ethnography. In Handbook of ethnography. P. Atkinson, A. Coffey, S. Delamont, J. Lofland, \& L. Lofland (Eds.). Thousand Oaks, CA: Sage.

Roethlisberger, F. \& Dickson, W. (1939). Management and the worker. Cambridge, MA: Harvard University Press.

Ruddell, R. (2004). America Behind Bars: Trends in imprisonment, 1950-2000. New York, NY: LFB.

Ruiz v. Estelle (1980). 503 F.Supp. 1295

Simon, J. (2000). The "Society of Captives" in the era of hyper-incarceration. Theoretical Criminology, 4, 285-308.

Stacey, J. (1988). Can there be a feminist ethnography? Women's Studies International Forum, 11, 21-27.

Stoddart, K. (1986). The presentation of everyday life. Urban Life, 8, 135-152.

Sykes, G. (1958). The society of captives. Princeton, NJ: Princeton University Press.

Wacquant, L. (2002). The curious eclipse of prison ethnography in the age of mass incarceration. Ethnography, 3, 371-397.

Walker, S. (2001). Sense and nonsense about crime and drugs: A policy guide. Belmont, CA: West/Wadsworth.

West, H. \& Sabol, W. (2008). Prisoners in 2007. Bureau of justice statistics bulletin. Washington DC: U.S. Government Printing Office.

Zimring, F. \& Hawkins, G. (1995). Incapacitation: Penal confinement and the restraint of crime. New York, NY: Oxford University Press.

\section{Contributor}

Scott Chenault is an Assistant Professor and Chair of the Criminal Justice Department at the University of Central Missouri. His primary research is in the area of correctional staff and programming. He also conducts research on Criminal Justice higher education and the interaction 
between the criminal justice system and the media. His previous work has appeared in ACJS Today, the Journal of Criminal Justice Education, and in the Sociology journal Symbolic Interaction.

\section{Footnotes}

1. Prairie is a pseudonym for a medium sized department of corrections in a Midwestern state. This represents another important distinction; there are certainly cultural differences between Southern Corrections and Midwestern Corrections regardless of era. $\bullet$

2. The key to this discussion is the term spontaneous. Today the majority of physical confrontations with inmates are pre-planned cell extractions. While these encounters require a level of courage on the part of the officers, they are typically not voluntary activities. In other words, a commanding officer assigns a series of officers to perform the cell extraction. Thus, an officer can reveal he/she completely lacks courage by refusing to participate. This will not demonstrate possession of courage by participating, but will show willingness to follow orders.

3. The taboo on physical violence toward inmates was present in the prisons in my study. Other prisons may not adhere to this same taboo, and there is ample evidence to suggest that violence directed toward inmates still occurs in modern prisons. $\leftrightarrows$

4. An important side effect of not being paid, in addition to the freedom it granted me, was the respect I earned from officers. Several officers commented that they hated their jobs even with the meager pay, so they could not imagine doing it for free, as I was. 